\title{
Explicating Kafka's Metamorphosis within the ambit of Marxism
}

\author{
Shabir Ahmad Mir \\ Department of English, Is lamic university of science and technology, Awantipora, jammu and Kashmir, India \\ optimist821@gmail.com
}

\begin{abstract}
Franz Kafka's au courant; "The Metamorphosis" recounts the preposterous and bizarre tale of the travelling salesman 'GregorSamsa' and his unanticipated transfiguration into a giant species of vermin. Kafk a transforms the metaphor into a narrative with a minutely detailed bourgeois setting. The incongruous tale of GregorSamsa is embedded with multiple layers of significance and many layers have been peeled down till nowand brought before the world of literature by various scholars and amateur contemporary writers. On the veneer stratum, Kafka's novella published in 1916, appears tobe just a tale of a travelling sales man who found himself transformed into an insect after he woke up one morning, but ruminating deeply overSamsa's transfiguration with the two bigwigs of Marxism, Karl Marx and Engel's economic theories, unveils an overreaching metaphor that judiciously provides the dubious story a great deal of pertinence to the structure of society. The paper however succinctly purports to explicate Franz Kafka's novella in light of the Marxist approach.
\end{abstract}

Keywords- Metamorphosis, vermin, incongruous, Marxism, explicate, au courant, Franz Kafka, Karl Marx.

\section{INTRODUCTION}

Franz Kafka was a German novelist of the $20^{\text {th }}$ century, popular for the chef d'oeuvre, "The Metamorphosis". His best known works include "Die verwandlung"(the Metamorphosis), "Der process" (The Trial), and"Das schloss" (The Castle).these works have notwithstanding have given birth to the term 'Kafkaesque 'to render situations like those of his writing. He has been expounded as probing the themes of guilt, existential anxiety, and absurdity.

The Metamorphosis is read as a la mode of $20^{\text {th }}$ century literature, originally written in German(Die Verwandlung) by Franz Kafka. At the surface level this is an improbable tale of a travelling salesman who finds himself transformed into an insect. The novella has been disentangled at multiple levels, focussing primarily on GregorSamsa who wakes one morning to find himself unaccountably transformed into anungeheuresungeziefer, a monstrous vermin, ungeziefer being a general term for unwanted and unclean animals, and battling with this agitating figure to survive. Kafka asks the reader to suspend reality and accept a large distortion through his turning of GregorSamsa into a vermin. His transformation has become a cynosure of everyone's eye that read him and has been interpreted at different levels and thus becoming a kaleidoscopic read for the present scholars of literature. The design of the paper is to divulge Kafka's magnum opus through the materialistic philosophy of Karl Marx (1818-1883) and Friedrich Engels (182018950).the paper purports to highlight the literary genre in terms of the social period which produced it. The students and researchers who want to conduct research in the genre can harness this study as a frame of reference.

\section{SOME BASIC TENETS OF THE CREDO OF MARXIS M}

Marxism is a materialist philosophy that aims to explain things without assuming the existence of a world, or of forces, beyond the natural world around us, and the society we live in.it looks for concrete, scientific, logical explanations of the world of the observed fact. (Its opposite is idealist philosophy, which doesn't believe in the existence of a spiritual 'world elsewhere). The purpose of Marxism is to bring a classless society based on the common ownership of the means of production, distribution and exchange. The tradition of, Marxist thought has however provided the most powerful critique of capitalist institutions and ethics ever conducted. Its founder is the German political, economic and philosophical theorist and revolutionist Karl Heinrich Marx. The other important figure related to Marxism was Friedrich Engels, whose importance lies in his collaboration with Marx to produce a critique of capitalist society based on a materialist conception of history. His most popular work in the field of Marxism is "The condition of working class in England" published in 1845.in the book, he contends that the degraded conditions of the English proletariat, generated by their industrial exploitation, and would eventually mould it into a revolutionary political force. The concern would be discussed later in relation to Kafka's protagonist, George Samsa. Marx on the other hand saw this economic exploitation as underlying the ultimate downfall of 
capitalism. Karl Marx has produced a sui generis named as "Das capital” published in 1867.

The simplest Marxist model of society sees it as constituted by a base (the material means of production, distribution and exchange) and a superstructure, which is the 'cultural' world of ideas, art, religion, law and so on. The essential Marxist view is that the latter things are not 'innocent' but are determined (or shaped) by the nature of the economic base. This belief about culture, known as economic determinism, is a central part of traditional Marxist thinking. This vital imposition of the Marxist approach would provide further raw material in discussing, how Kafka'smetamorphosis divulges underlying overtones of Marxism.

\section{Defining the terms associated with Marxism}

The terms will be very conducive in understanding how 'the Metamorphosis' is related to Marxism.

Ideology: is a key term for all Marxists spoofed by Althusser. Althusser's definition (quoted by Goldstein) is a follows:

Ideology is a system (possessing its logic and proper rigour) of representations (images, myths, ideas or concepts according to the case) endowed with an existence and an historical role at the heart of a given society.

Proletariat: the labouring class, especially the class of industrial workers who lack their own means of production and hence sell their labour to live. The proletariat is the lowest social or economic class of a community and therefore a thing of disdain and jeer.

Bourgeois: marked by a concern for material interests and respectability and a tendency towards mediocrity. This class is dominated by commercial and material interests.

Mechanical materialism: according to this view ordinary happens of life are directly related to prevailing social force.as mere products o society, people seem to live a life of bondage in their surroundings. Also individuals are considered slaves to the instincts and, therefore, react to the circumstances on the basis of knowledge gained through senses.

Necessity: this refers to the constraints of social environment which have to be accepted as what Marx calls 'conditions of existence'. The more we know about the world of necessity, the better will our chances be of overcoming or changing it.

Misappropriation: it indicates the unjust nature of surplus distribution under which socially produced surplus is wrongly snatched away by the individual entrepreneur. Under this arrangement, the actual producer, the factory worker, merely gets his wages, not a share in the produce.

Essence: an important Marxist concept wrongly interpreted as abstracted truth. Es sence should be seen the significant idea or aspect that evolves centrally through the interplay of happenings of life, as for instance 'class essence' of a social event.

Analysing 'The metamorphosis' in the light of Marxism

Kafka's 'the metamorphosis' though blatantly appears to be just a vanilla for plain minds, just a simple tale of a travelling salesman transforming into a giant insect, but beneath the iceberg, lies a vast mass of interpretations. The tale has been unravelled at multiple levels by the enormous students and scholars of English literature. Nonetheless, the book couldn't help itself to conceal the overtones of the philosophy of Marxism. These underlying connotations can't be unmasked without a trenchant and profound analysis into the character of its protagonist, George Samsa.

However by employing the Marxist approach, the novella unveils an overreaching metaphor that provides the farfetched story a proficient pertinence to the structure to the society that the Marxists aim to expound. George samsa, the central figure and the protagonist isn't only a character who provides an improbable story, but he is a representative of a labouring class, devoid of the means of production and thus signifies a proletariat (a term employed by the Marxists for the lowest economic and social class).George samsa is the victim of the highest social and economic wrath who had to survive under a wretched policies. He becomes an object of disdain in the hands of the Machiavellian scheme. His manager under whose command he works can be seen as the representative of the bourgeois. After the wretched metamorphosis of George Samsa, there arises an acute discordance and turns into a severe conflict and that doesn't undermine the authority of the bourgeois, but only renders Samsa unemployed and thus gesturing towards the impersonal and dehumanizing structure of class relations.in one of the conversations between the manager and George Samsa, the vulnerability of the uneconomical class is evident when Samsa utters;

"Mr. Manager! Take it easy on my parents! There is really no basis for the criticisms which you are now making against me, and really nobody has said a word to me about that".

George Samsa realistically unmasks himself and reveals the proletarian hallmark. While in bed, he dismally comments on his life as a travelling salesman;

'O God,' he thought, 'what a demanding job I've chosen day in, day out on the road. The stresses of trade are much greater than the work going on at head office, and, in addition to that, I have to deal with the problems of traveling, the worries about train connections, irregular bad food, temporary and constantly changing human relationships which never come from the heart". 
The metaphor of the equivocal story can be fragmented into three parts (despite their overlapping in the story) first Kafka employs the characters who signify their respective economic classes. Next, he judiciously details George's metamorphosis and the way this wretched transformation handcuffs and callously encumbers his labour .this metamorphosis a huge boulder in front of him and which he finds an uphill task to surpass eventually, he renders the final results of the workers impotence to work: abandonment by his family and death. Kafka fantastically paints a complete scenario of throes and hardships among the economic class. The above passage contains enough evidence of the tantalizing position of George Samsa as a labourer. He has no other option other than to continue suffer without going against it. He tries to give vent to his wretched condition;

"I have got the torture of travelling, worrying about changing trains, eating miserable food at all the hours..."

His wailings and complaints can't bring him any ease, but only aggrandizes his agitation. His only way of escape is to suffer and continue to working at his humdrum job, because he is a member, 'the modern class wagelabourers' who are devoid of their own means of production. He is fully acquainted in his own heart of hearts that he is doomed to survive under the terrible paws of labouring he says;

“... If I didn't hold back for my parents' sake, I would've quit ages ago. I would've gone to the boss and told him just what I think from the bottom of my heart. He would've fallen right off his desk! How weird it is to sit up at the desk and talk down to the employee from way up there. The boss has trouble hearing, so the employee has to step up quite close to him. Anyway, I haven't completely given up that hope yet."

However, after getting acquaintance about the proletariat in the Marxist approach through the character and role of the protagonist, George Samsa, it is essential to know about the bourgeois (term used by the Marxists for the modern capitalists).

George Samsa's manager is the representative of the bourgeois, or "the class of modern capitalists" owners of the means of and employers of the wage- labour production" the Manager whose name isn't revealed, appear as an unspecified is described as onerous, insensitive and impersonal.it is an admitted fact as well as an established reality that Kafka's attempt to keep him anonymous signifies his lack of humanity.in the novella, George Samsa enunciates that the manager; 'Sits on the desk and talks down from the heights to the employees" The manager feigns to be superior to the workers, because of his refined and advanced economic berth. His only cynosure of eyes is the production of his workers.in the novella, when George Samsa is few hours late in getting to work after five years of being on time every day, the manager travels to his house to personally reprimand him. Because, as a component of the bourgeois, the manager doesn't possess any labour of his own to perform. He is a handicapped member of the bourgeois who can't move and work by his own.

The chief strife and discordance in the novel is therefore the transformation of George samsa into a "monstrous vermin" that serves as a metaphor for any type of impairment that renders the worker unable to work.

"At first he wanted to get of the bed with the lower part of his body, but this lower part (which he incidentally had not yet looked at and which he also couldn't picture clearly) proved itself too difficult to move. The attempt went so slowly. When, having become almost frantic, he finally hurled himself forward with all his force and without thinking, he chose his direction incorrectly, and he hit the lower bedpost hard. The violent pain he felt revealed to him that the lower part of his body was at the moment probably the most sensitive".

The specific characteristics of George Samsa's insect form are relatively unimportant to the understanding of the class struggle that is taking place. Because of this, the narrator's description of the bug is rather vague. Instead what the story focuses on is the way in which Georger's value a labourer diminishes when he is unable to work. What the story mainly focuses is on is the way in which Georger's worth as a labourer declines swiftly when he is unable to work.as soon as his value wafts away, his manager as well as his family and even his own vestigial life abandon him and leave him into a very lugubrious and eremite quarantine death.

In the novel, it is clear that George Samsa at the first instant was callously marooned by his Manager, who is the representative of the bourgeois. According to Marx and Engels, the bourgeoisie;

"has resolved personal worth into exchange value, and in place of the numberless and indefeasible charted freedoms, has set up that single, unconscionable freedomfree trade in one word, for exploitation, veiled by religious and political illusions, naked, shameless, direct, brutal exploitation".

As soon as the manager saw that Gregor in his transformed state, he fled the house and never returned or sent any word to the family. An obvious interpretation of this is that he was afraid of the insect form Gregor had taken. But, in relation to the metaphor of the story, his realization that Gregor was unable to work caused him to calculate that the Gregor no longer had any value and therefore he abandoned him. To the bourgeoisie, the worker is worth nothing more than his labour. Therefore, without any labour to offer, Gregor was worthless and expendable. 
'Mr.Samsa,' the manager was now shouting, his voice rose, 'what's the matter? You are barricading yourself in your room, answer with only a yes and a no, are making serious and unnecessary troubles for your parents, and neglecting (I mention this only incidentally) your commercial duties in a truly unheard of manner. I am speaking here in the name of your parents and your employer, and I am requesting you in all seriousness for an immediate and clear explanation. I am amazed. I am amazed".

It is ironic that after years of working a job he hated to pay off his father's debts, for which he is so quickly discarded by his father as soon as he can no longer earn wages.

After Gregor becomes unable to support his family financially, they all eventually abandon him as well. Marx and Engels state that;

"The bourgeoisie has torn away from the family its sentimental veil, and has reduced the family relation into a mere money relation"

The Metamorphosis serves as an example of this by showing that when Gregor was no longer able to provide his family with money, his relationship with them was severed. Gregor's father, with whom he had little emotional attachment, was the harshest in dealing with Gregor. He never offers to help his son in any way after the transformation. Upon first seeing his transformed son, he "clenched his fists, as if to drive Gregor back into his room". Then, one day when his son is trapped outside of his room, he attacks him by throwing fruit. Although this scene sounds almost comical, the apple that he threw left Gregor with a "serious wound, from which he suffered for over a month".

The eventual result of Gregor's metamorphosis, and the corresponding inability to labour, was his death. Being unable to feed himself, Gregor's fate was dependent on the charity of his family, which eventually became meagre enough that he starved to death. The cleaning lady came upon his corpse one morning and quickly informed the family. Upon hearing the news, they did not show sadness, but instead relief. Mr.Samsa's comment was, "Well... now we can thank God!". He was happy to be freed of the economic burden of supporting his son. Instead of mourning, the family decided to travel to the country to enjoy the warm sunshine. And instead of reminiscing about their lost son, they spoke of the economic benefits of his death and of their future financial plans. Because of his inability to work, Gregor had become worthless to the family and would not be missed. No matter how much they may have loved him while he was an asset; they could not love him while he was a liability. Although the exact story told in Kafka's The Metamorphosis could not occur outside the realm of fantasy, it represents the very real scenario of a worker being abandoned by his employer and family after becoming unable to work and support them financially. By looking at the novella from a Marxist perspective, we see that the underlying theme of the story is a conflict between proletariat and bourgeoisie. Because economics supersede everything else in capitalistic society, a citizen who is unable to labour and earn wages is quickly abandoned. And, the result of this abandonment is often (as it was in GregorSamsa's case) death.

'What now?' Gregor asked himself and looked around him in the darkness. He soon made the discovery that he could no longer move at all. He was not surprised at that. On the contrary, it struck him as unnatural that he had really been able up to this point to move around with these thin little legs. Besides he felt relatively content. True, he had pains throughout his entire body, but it seemed to him that they were gradually becoming weaker and weaker and would finally go away completely. The rotten apple in his back and the inflamed surrounding area, entirely covered with white dust, he hardly noticed. He remembered his family with deep feeling and love. In this business, his own thought that he had to disappear was, if possible, even more decisive than his sister's. He remained in this state of empty and peaceful reflection until the tower clock struck three o'clock in the morning. From the window he witnessed the beginning of the general dawning outside. Then without willing it, his head sank all the way down, and from his nostrils flowed out weakly out his last breath.

Thus with the death of George Samsa proves the fate of a proletariat (George Samsa) under the stewardship of a callous bourgeois (The Manager).

\section{REFERENCES}

[1] Abrams, M.H. A Glossary of Literary Terms.India: Thomson Business International India Pvt.Ltd, 2006.Print.

[2] Barry, Peter. Beginning Theory.UK: Manchester University Press, 2010.Print.

[3] Cuddon, J.A.The Penguin Dictionary of Literary Terms and Literary Theory. London: Penguin, 2000.Print.

[4] M. A. R. Habib, A history of literary criticism and theory: Oford, U.K, 2008 print.

[5] Chris Baldick, Oxford dictionary of literary terms, Oxford University Press, 1990 print.

[6] M. H. Abrams and Geoffrey Harpham, A glossary of literary terms, Cengage learning Indiapvt.Ltd, 2015 print.

[7] Kafka, Franz. The Metamorphosis. New York: Bantam, 1986. Buy a copy.»

[8] Karl Marx and Friedrich Engels. The Communist Manifesto.; The Norton Anthology of Theory and 
Criticism. Ed. Vincent B. Leitch. New York: Norton, 2001.

[9] Terry Eagleton, The function of criticism (London: New Left Books.1984, p.93.

[10] Terry Eagleton,Literary theory An introduction (oxford and Minnesota: Blackwell/ University of Minnesota press, 1983) p.208.

[11] Antonio Gramsci, Selections from political writings, trans. J, Mathews (New York: international publishers, 1977. 